\title{
Strawberry breeding in Brazil: current momentum and perspectives
}

\author{
André Ricardo Zeist ${ }^{1} \mathbb{D}$; Juliano Tadeu V de Resende ${ }^{2} \mathbb{D}$ \\ ${ }^{1}$ Universidade do Oeste Paulista (UNOESTE), Presidente Prudente-SP, Brazil; andrezeist@unoeste.br; ${ }^{2}$ Universidade Estadual de \\ Londrina (UEL), Londrina-PR, Brazil; jvresende@uol.com.br
}

\begin{abstract}
Brazil depends almost entirely on imported strawberry cultivars, which burdens production costs and results in the use of genotypes with less adaptation to the Brazilian cropping conditions. To reverse this scenario, it is necessary to strengthen strawberry breeding in Brazil. Otherwise, the country will remain dependent on imported cultivars and producers will continue to be required to collect royalties. In this context, public institutions in Brazil, such as the State University of the Midwest Paraná (UNICENTRO), have been successfully conducting strawberry breeding programs, with the objective of launching cultivars in the short term. Crosses between the cultivars in use in the country, with the subsequent development and selection of seedlings, have shown to be the way to generate national genotypes better adapted to the tropical and subtropical climate conditions of Brazil. In this work, in addition to the main results obtained so far by the UNICENTRO strawberry breeding program, we report information on strawberry origin, taxonomy and phylogenetic description, genotype sensitivity to photoperiod, breeding history in Brazil, and objectives, methods, and techniques employed by the current strawberry breeding in Brazil.
\end{abstract}

Keywords: Fragaria x ananassa, intraspecific crosses, breeding program, review.

\begin{abstract}
RESUMO
Melhoramento genético do morangueiro no Brasil: atualidades e perspectivas
\end{abstract}

O Brasil depende quase que na totalidade de cultivares de morangueiro importadas, o que resulta em custos mais altos para os produtores e menor adaptação dos genótipos às condições brasileiras de cultivo. Para reverter este cenário, é necessário maior enfoque ao melhoramento do morangueiro no Brasil; caso contrário, o país continuará dependente de cultivares importadas, o que obriga o pagamento de royalties. Em vista dessa situação, instituições públicas do Brasil, como a Universidade Estadual do Centro-Oeste do Paraná, vêm conduzindo programas de melhoramento genético do morangueiro com sucesso, com o objetivo de lançar cultivares em curto prazo. Cruzamentos entre as cultivares em uso no país, com a posterior obtenção e seleção de seedlings, têm demonstrado ser o caminho para gerar genótipos nacionais mais bem adapatados às condições de clima tropical e subtropical do Brasil. Neste trabalho, além dos principais resultados obtidos até então pelo programa de melhoramento genético do morangueiro da Universidade Estadual do Centro-Oeste, são apresentadas informações referentes à origem, descrição taxonômica e filogenética, sensibilidade dos genótipos ao fotoperíodo, histórico do melhoramento genético no Brasil, objetivos do melhoramento e métodos e técnicas de melhoramento do morangueiro empregadas no Brasil.

Palavras-chave: Fragaria $\mathrm{x}$ ananassa, cruzamentos intraespecíficos, programa de melhoramento genético, revisão.

\section{Received on November 20, 2018; accepted on March 13, 2019}

$\mathrm{S}_{\mathrm{s}}^{\mathrm{t}}$ trawberry is the most cultivated and consumed small fruit in the world (Tazzo et al., 2015). Its regular use in daily meals increases the consumption of antioxidants and other substances important to improve human health (Andrianjaka-Camps et al., 2017; Michalskaa et al., 2017). In Brazil, strawberries come mainly from small farms and there is an increasing trend in both the cultivated area and production in recent years (Witter et al., 2012; Richter et al., 2018). Figures from 2016 (FAO, 2018) show China as the world largest producer, with more than 3.7 million tons, followed by the United States (1,420,570 t), Mexico
$(468,248 \mathrm{t})$, Egypt $(464,958 \mathrm{t})$, and Turkey $(415,150 \mathrm{t})$. In the same year, Brazil harvested approximately 155,440 tons of strawberries in 4,300 hectares, resulting in an average yield of $36.1 \mathrm{tha}^{-1}$ (Fagherazzi et al., 2016b).

The main strawberry cultivars used in Brazil come from breeding programs carried out in the United States. The leading materials are cultivars Oso Grande, Camarosa, Aromas, Diamante, Camino Real, Albion, Monterey, San Andreas, Palomar, and Portola, developed at the University of California; and cultivars Dover, Sweet Charlie, and Florida Festival, developed at the University of Florida. The dependence on foreign genetic materials and nurseries results in increases in the strawberry production costs in Brazil (Fagherazzi et al., 2017a) due to expenses in the importation of seedlings and payment of royalties own to property right agreements. In addition, imported seedlings generally only arrive in Brazil on the end of April, in detriment to producers of regions where climatic conditions allow cropping seasons to begin in March. Finally, there are the risks associated with the possibility of introducing pathogens and pests along with seedlings.

Speeding up the Brazilian strawberry breeding programs is the most effective 
strategy to reduce the dependence of imported cultivars. Local breeding would be in the position of offering high-quality genetic material, well adapted to the Brazilian conditions, to the strawberry chain. However, most of the Brazilian strawberry breeding programs are currently stagnant or at a low pace. The development of Brazilian cultivars may also attract new farmers, contribute to prevent rural exodus and strengthen family-based farming systems. Nevertheless, the development of new cultivars adapted to the tropical and subtropical climate of Brazil demands the commitment of professionals from several sub-areas of agronomic knowledge, once it requires the assessment of tolerance to pathogens and pests and the evaluation of plant morphological and productive characteristics and fruit physicochemical traits.

Productivity in strawberry is influenced mainly by the interaction between temperature and photoperiod, soil conditions, and the incidence of pests and pathogens. Such a combination makes the identification of promising materials in the early stages of the breeding program into a challenge. Additional difficulties the Brazilian strawberry breeding programs face are the uneven seedling germination, the need to accumulate desirable traits into single genotypes and to produce clones free from pathogens and pest arthropods.

\section{Strawberry origin}

Strawberry cultivation started in Sec. XIII, in France, by transplanting wild-caught Fragaria vesca plants to gardens with ornamental purposes. Soon, it was realized that the fruits were tasty, and then the French and English royalties strawberry started consuming and appreciating it (Duschesne, 1766; Darrow, 1966). From 1500, strawberry cultivation became increasingly popular all over Europe. The first strawberry botanical illustration dates back to 1485, from the Mainz Herbarium Herbariuse (Germany). At the end of the $18^{\text {th }}$ century, the literature on botany and natural sciences already included several strawberry species, such as $F$. moschata (most common in England and Russia), $F$. viridis and $F$. vesca (most common in the European gardens) (Darrow, 1966).

Strawberry cultivation gained momentum in Europe from 1600 due to the introduction of two species, $F$. virginiana and $F$. chiloensis, brought from America (Darrow, 1966; Zawadneak et al., 2013). In 1764, the botanist Antoine Nicolas Duchesne formed a strawberry collection with specimens coming from all over Europe. Such collection served to the studies that ended up revealing that the $F$. chiloensis plants grown in Europe produced only female flowers. Therefore, fruit production took place only when $F$. chiloensis had neighbor plants from other species. It was also observed that the casual cross between $F$. chiloensis and $F$. virginiana resulted in very aromatic fruits, remembering the pineapple, which botanists denominated Fragaria x ananassa (Darrow, 1966). This species quickly spread throughout Europe and, later, to the other continents.

The precise introduction of strawberry in Brazil is unknown. Nonofficial information suggests that the commercial-scale planting began around 1950, in the states of São Paulo, Minas Gerais, and Rio Grande do Sul and expanded in the following decade with the launching of cultivar Campinas. Darrow (1966) and Zawadneak et al. (2013) report comprehensive information on strawberry history, origin, and genealogy.

\section{Taxonomic description and phylogenetics}

Strawberry belongs to the genus Fragaria (Cronquist, 1988) along with more than 45 described species. However, only 20 species occur in nature currently (Hancock et al., 2008; Marodin et al., 2018).

The cultivated strawberry, Fragaria $\mathrm{x}$ ananassa, is an octoploid, with seven basic chromosomes $(2 \mathrm{n}=8 \mathrm{x}=56)$ (Hancock et al., 2008). After several years of study, Staudt (2009) systematized four important characteristics to the strawberry taxonomic classification: number of chromosomes; stolon branching; sexual expression and other crossing mechanisms, and pollen grain morphology. Using these characteristics,
Staudt (2009) grouped the strawberry species based on different ploidy levels (diploid, tetraploid, hexaploid, octoploid).

Different ploidy levels make it difficult to clarify the phylogeny of Fragaria. Federova (1946) presented the first genomic formula (AABBBBCC) and, Senanayake \& Bringhurst (1967), the second (AAA'A'BBBB), later revised by Bringhurst (1990) (AAA'A'BBB'B). More recent studies, based on sequences of nuclear and chloroplast genes and morphological characteristics, suggest the genomic formula YYY'Y'ZZZZ/YYYYZZZZ, in which the contribution of two to four diploid species to the octoploid species is noticed. This proposition supports the allopolyploid origin of the hexaploid $F$. moschata and of the octoploids F. chiloensis, F. iturupensis, and $F$. virginiana (Rousseau-Gueutin et al., 2009).

The diploid sources of the octoploid genome are still unclear, but $F$. vesca, $F$. mandshurica, and F. iinumae are the most likely candidates (Hummer \& Hancock, 2009; Rousseau-Gueutin et al., 2009; Tennessen et al., 2014). The octoploid genome has an estimate of $698 \mathrm{Mb}$ or $80 \%$ of the quadruplicated size of the diploid genomes $(* 200 \mathrm{Mb}$ each) (Hirakawa et al., 2014). F. vesca is the species most studied among the parents of the cultivated strawberry and is also the species most used as a genetic model for the Rosaceae family, as it has a relatively small genome (Shulaev et al., 2011).

\section{Genotype sensitivity to photoperiod}

In general, three factors influence the most the strawberry response to photoperiod: genotype, temperature, and exposure of the seedlings to the cold (Stewart \& Folta, 2010). Darrow (1936), in his first studies on this subject, observed that most of the genotypes produced more flowers under photoperiods ranging from 9.5 to 13.5 hours, considering 12 hours as optimal. However, recent studies showed that the most abundant flowering occurs in photoperiods ranging between 8 and 12 hours (Stewart \& Folta, 2010). 
According to Darrow (1966), the first cultivated octoploid genotypes flowered under short days, although there was considerable variation in the sensitiveness to the photoperiod and in the required number of hours of light. As breeding programs advanced and hybridizations were carried out, as well as more detailed studies appeared, genotypes setting flowers with photoperiods of up to 14 hours were also considered as of short days (Faedi et al., 2002).

Although floral induction requires short photoperiods, if short days persist, they may delay the development of the previously initiated buds if compared to longer photoperiods (Durner \& Poling, 1987). Therefore, strawberries are shortday plants for floral induction, but longday for flower and fruit development. Examples of short-day cultivars planted in Brazil are Milsey Tudla, Cartuno, Sweet Charlie, Big Bear, Camarosa, Gaviota, Ventana, and Camino Real.

There are also strawberry plants with no sensitivity to photoperiod. $F$. virginiana subsp. glauca, which flowers in summer and autumn, was the first species in which researchers observed this behavior (Darrow, 1966). Breeding programs evaluated and incorporated a large number of $F$. virginiana subsp. glauca genotypes in the 1930s and 1940s. The greatest impact of $F$. virginiana subsp. glauca over strawberry breeding occurred in the 1970s, at the University of California, when researchers used a single accession of the species from the Wasatch Mountains in Utah to introgress the flowering habit into the cultivars then in use (Bringhurst \& Voth, 1984). The strawberries derived from this single source constituted the majority of the cultivars planted in California in 1999, called neutral day cultivars (Hancock et al., 2005; 2008). The characteristic had a simple and dominant inheritance in this case and was incorporated with only three backcrosses (Bringhurst \& Voth, 1978).

Neutral-day cultivars are more tolerant to heat and have longer harvesting periods, but are more difficult to propagate and develop fewer runners. Examples of neutral-day cultivars used in Brazil are Aroma, Diamond, Pacific, Selva, Seascape, Albion, Portola, Monterey, and San Andreas. Currently, Brazilian farmers prefer these cultivars. However, considering the Brazilian edaphoclimatic variability, it is imperative that the local strawberry breeding develop both short- and neutral-day cultivars.

\section{Strawberry breeding in Brazil}

Strawberry breeding had its first impulse in England in the early XVIII century, expanding to France, Germany, and the United States later (Zawadneak et al., 2013). In Brazil, the Agronomic Institute of Campinas (IAC) was the pioneer in strawberry breeding, starting in 1941, followed by the Experimental Station of Pelotas, now Embrapa Clima Temperado, in 1950. These programs developed and used several materials obtained from the importation of seedlings and achenes from breeding programs in the United States.

The Brazilian breeding programs were decisive to increase strawberry productivity and importance in the country. The IAC program launched the cultivars Campinas (IAC 2712), Guarani (IAC 5074), Monte Alegre (IAC 3113), and Princesa Isabel (IAC 5277); while Embrapa's launched Santa Clara, Konvoy-Cascata, and Vila Nova (Oliveira \& Bonow, 2012). However, from the 1990s, improved cultivars developed by foreign programs were successfully introduced in the Brazilian producing regions and replaced the national cultivars planted at that time.

Currently, the cultivars most used in Brazil come from American breeding programs, which implies great dependence and vulnerability to the local strawberry chain (Fagherazzi et al., 2017a,b). In recent years, a few Brazilian institutions, such as Embrapa Clima Temperado, the State University of Santa Catarina, the Federal University of Lavras, the State University of Midwest Paraná, the State University of Londrina, and the University of Oeste Paulista (the last two, from 2019) started developing new strawberry genotypes, well adapted to the Brazilian soil and climatic conditions. However, so far the Brazilian programs have not released national genotypes capable of competing in yield with the imported cultivars, widely used in Brazil.

\section{Breeding objectives}

The success of a strawberry breeding program depends on a number of factors, and the definition of objectives and goals is fundamental for saving time and resources. In general, strawberry breeding programs should pursue meeting the demands, from farmers to consumers, and keeping updated with the constant changes in production systems. To develop new strawberry genotypes with high agronomic performance and nutritional quality of fruits is a laborious and complex process (Mezzetti et al., 2018).

Several objectives of the Brazilian strawberry breeding programs are common to any crop, such as increased productivity in local conditions and resistance to pests and diseases. However, there are some characteristics that are almost specific to strawberries, such as fruit color, reduced number of runners, and a few canopy traits, among others. Brazilian strawberry breeding programs should tackle the following aspects to develop genotypes able to exceed or to perform as good as the imported cultivars:

1. To increase or maintain crop yields to guarantee farmers' profitability;

2. To incorporate or increase the level of resistance/tolerance to pests and pathogens to reduce the need for spraying protection products and decrease quantitative and qualitative losses in the field and post-harvest;

3. To increase plant adaptation to the Brazilian tropical and subtropical conditions, as well as to different soil types and cropping systems;

4. To incorporate into cultivars characteristics to make harvests easier, like fruit production far from the center of the canopy;

5. To increase the water and nutrient uptake and use efficiency and to introgress genes of tolerance to abiotic stresses;

6. To extend the cropping season to the summer (neutral day cultivars) to allow for harvesting in unusual periods 
with added-value;

7. To improve fruit sensorial acceptance, which is dependent on good physical-chemical quality, especially intense red color and high contents of soluble solids and aromatic volatiles;

8. To produce uniform fruits, preferably above 20 grams, to reduce labor costs and increase consumers' acceptability;

9. To increase fruit firmness to reduce damage during harvesting, packaging, distribution, and commercialization;

10. To improve the fruit nutritional quality, which should be relatively stable despite the edaphic conditions and climatic zones, that must have a significant impact on human health;

11. To develop cultivars that meet the requirements of both the fresh and processing markets, with fruits displaying physical and chemical characteristics peculiar to each segment, and;

12. To address global issues related to the environment, agriculture sustainability, food safety, and quality, which are all challenging aspects to strawberry breeding in Brazil and elsewhere.

\section{Productivity}

The productive potential of a strawberry genotype depends on the size and number of fruits. The ideal cultivar should produce large fruits, in shapes that meet the consumers' requirements. Large fruit is the recessive phenotype (quantitative genes) in most cultivars currently used in Brazil. The number of crowns per area has also been associated with yield (Cocco et al., 2011). However, the genetics behind the number of crowns per area has not received much attention.

Strawberry yields in Brazil increased after the release of cultivar Campinas, from IAC, in 1955 (Castro et al., 2003). Cultivar Campinas resulted from crossing the North American cultivars Donner and Tahoe (Camargo et al., 1968) and was the leading strawberry cultivar in the main Brazilian producing states for more than 30 years. Cultivar Princesa Isabel is another Brazilian material that stands out. Launched in the 80 's from the cross between cultivars Germany and Jundiaí, Princesa Isabel has good productive characteristics, such as high yield, earliness, and large fruits (Castro et al., 2003). Currently, the imported cultivars outyield those developed by the Brazilian breeding programs.

The Center for Agronomic Sciences of the State University of Santa Catarina (CAV-UDESC) introduced 15 strawberry genotypes from Italy in 2013 (Fagherazzi et al., 2017a). Cultivars Jonica [obtained from the natural pollination of cultivars Rosalinda $\mathrm{x}$ Demetra (Irvine $x$ Tudla)] and Pircinque (obtained from the cross between cultivars Ventana x Nora) still stand out, yielding more than $500 \mathrm{~g}_{\text {plant }}{ }^{-1}$. However, these two cultivars, along with all those widely cultivated today in Brazil, do not have a genetic base directed to the Brazilian soil and climatic conditions. Recent studies show that the hybridization of different strawberry genotypes followed by local selection, as the pioneer Brazilian strawberry breeding programs did (Camargo et al., 1968), may result in the development of more productive and better-adapted cultivars (Barth, 2017, Galvão et al., 2017, Vieira et al., 2017).

Crosses between cultivars Camarosa and Aromas resulted in high yielding hybrids, with large fruits, meeting commercial standards in the south of Minas Gerais state (Galvão et al., 2017). In addition, crosses Dover x Aromas and Camarosa $\mathrm{x}$ Aromas resulted in $28.6 \%$ hybrids with total fruit mass superior to Aromas, and 9.5 and $14.3 \%$ hybrids superior to cultivar Camarosa, respectively (Galvão et al., 2017). In the screening of populations in Guarapuava, Paraná state, hybrids from the cross between cultivars Camarosa and Aromas also stood out in terms of yield (Barth, 2017). Thus, cultivars Camarosa and Aromas bear a high concentration of favorable genes for breeding strawberry for high productivity under the Brazilian soil and climatic conditions.

There are two main ways to increase productivity through plant genetics and physiology: to increase the efficiency of photoassimilate production of or to change the dry matter partitioning
(Marodin et al., 2018). Several populations of $F$. chiloensis from United States and Chile have large fruits, which makes it easier to bred materials with large fruits and high yielding potential, or even high production of crowns and runners (Hancock et al., 2005; Luby et al., 2008). Therefore, an alternative to the success of the Brazilian breeding programs may be the introduction of $F$. chiloensis genotypes as donor parents for gains in fruit size.

\section{Resistance and tolerance to pathogens}

Pathogens pose challenges to strawberry production worldwide, resulting in increased costs due to yield losses and to the need for spraying protection products. Strawberry cultivars with some level of multiple resistances to pathogens could contribute significantly to mitigate difficulties (Nellist, 2018). Therefore, breeding for disease resistance has a high priority in many breeding programs worldwide (Kennedy et al., 2013, Pincot et al., 2018; Nellist, 2018).

In Brazil, the main diseases affecting strawberry are fungi: anthracnosis (Colletotrichum gloeosporioides, C. fragariae and C. acutatum), common leaf spot (Mycosphaerella fragariae), leaf scorch (Diplocarpon earliana), leaf blight (Dendrophoma obscurans), crown rot (Pestalotiopsis sp.), powdery mildew (Sphaerotheca macularis), Verticillium wilt (Verticillium dahliae), root rot (Rhizoctonia spp., Fusarium sp., Sclerotium rolfsii, Phytophthora spp.), red stele (Phytophthora spp), Rhizoctonia rot (Rhizoctonia spp.), mold-gray (Botrytis cinerea), and Rhizopus rot (Rhizopus spp.). Some bacterial diseases, such as the leaf spot (Xanthomonas fragariae) and viruses, such as Strawberry mottle virus, Strawberry crinkle virus, and Strawberry mild yellow edge virus (Antunes et al., 2016), are also relevant.

One of the main reasons for the low level of resistance of the cultivars used in Brazil to a large number of pathogens is the narrowing of the genetic basis to privilege production characteristics. Until then, strawberry breeding has been carried out in several countries, paying 
special attention to the increase in fruit number and size (Mezzetti et al., 2018). In addition, the genetic development of the foreign cultivars obviously did not consider the variability of the local pathogens. As an example, the imported cultivars are all susceptible to the crown anthracnosis ( $C$. fragariae) and to the fruit black spot (C. acutatum) (Oliveira \& Antunes, 2016), except for cultivar Sweet Charlie. The hybridization between imported cultivars (highly productive) and local genotypes (better adapted) is an interesting approach to develop new genotypes well adapted to the pathogenic and productive Brazilian soil and climatic conditions. Local genotypes can be Creole varieties and cultivars developed decades ago by the breeding programs of IAC and Embrapa.

The genetic resistance to pathogens can be lost after a few years of growing resistant plants in the field (Nellist, 2018). In general, resistance durability depends on the virulence pressure of a pathogen under cropping conditions, the genetic diversity of pathogenic isolates, and the possible changes in pathogenicity that may occur over time. Pyramiding or stacking resistance genes in a single cultivar, including, when available, both major and minor genes, with greater and smaller effect, respectively, and even stacking genes of smaller selection impact (Poland \& Rutkoski, 2016), can result in durable resistance. The combination of lower- and higher- or mid-effect genes has already shown to be effective in increasing genetic resistance (Brun et al., 2010).

The use of molecular markers and genomic studies to track large number of genes tend to increase the efficiency of breeding programs (Shiraev et al., 2011; Hirakawa et al., 2014; Whitaker et al., 2017). However, gene pyramidation is still a time-consuming process that involves multiple crosses when it comes to the resistance to strawberry pathogens.

\section{Fruit quality}

Pulp firmness and resistance to damage and fruit color, flavor, shape, aroma, and texture are the main traits related to fruit quality in strawberry
(Qin et al., 2008; Luby \& Shaw, 2009). However, the nutritional value and the antioxidant properties are becoming increasingly relevant, as health concerns are gaining ground (Singh et al., 2011; Mezzetti et al., 2016).

Pulp firmness and resistance to mechanical damage are key aspects for the strawberry breeding. The ideal fruits have the least possible damage during handling and transport, preserving their organoleptic qualities for the longest period. The University of California (UC) breeding program gained more than $47 \%$ in fruit firmness and appearance. Even then, there is hypothetically more variability still available for these characteristics (Shaw \& Larson, 2008).

The inheritance of the intensity of fruit color is partially dominant and, according to Santos (1999), shows heritability around $81 \%$. However, the genetic correlation between internal and external color is low, indicating that different genes control these characteristics (Marodin et al., 2018). Nonetheless, classical breeding methods are effective to achieve the ideal internal red and external dark red.

Taste and aroma result from the association of several factors, such as the presence of soluble acids and solids, for example. Aroma has quantitative inheritance and $41 \%$ heritability (Santos, 1999). The inheritance of the chemical characteristics affecting taste is not well elucidated yet (Whitaker et al., 2011). However, Sone et al. (2003) concluded that the inheritance of vitamin $\mathrm{C}$ contents is quantitative, although they also observed partial dominance in some progenies of crosses within $F$. x ananassa. Singh et al. (2011), working with cultivars Ofra, Chandler, Festival, and Camarosa, observed high heritability $(80 \%)$ for ascorbic acid and carotenoid contents and positive correlation of phenol content and contents of ascorbic acid, carotenoid and anthocyanin, and even with yield. Thus, phenol contents may be effective as biochemical markers to identify highyielding genotypes that simultaneously contain high levels of antioxidants.

Strawberry fruits play an important role in strengthening the nutritional value of the human diet by incorporating into it many nutritional and bioactive compounds, such as minerals, vitamin $\mathrm{C}$, folate, and phenolic substances (Giampieri et al., 2012). This aspect supports the increase in the number of fruit characteristics one should look at when breeding strawberries for benefits on human health (Mezzetti et al., 2016; 2018). Fruit quality should be always as important as yield and resistance to pathogens in strawberry breeding.

Classical breeding methods, as well as molecular-assisted breeding, are effective in increasing the contents of specific bioactive compounds (Giampieri et al., 2018) and may result in substantial advances in the years to come. The environmental and crop management influence over fruit chemical properties and firmness and other agronomic components are also relevant (Fan et al., 2011). Therefore, one should never leave behind the importance of the genotype $\mathrm{x}$ environment interaction when breeding strawberries (Gabriel et al., 2018), especially considering the demand for genotypes well adapted to the diversity of Brazilian soil and climatic conditions.

Methods and techniques of strawberry breeding used in Brazil

In strawberries, breeders can exploit all the genetic variance produced in a cross, be it additive, dominant or epistatic, since strawberries allow asexual (clonal) reproduction. Nevertheless, parents should have good genetic divergence to avoid inbreeding, which often results in vigor loss and a decrease in productivity (Gil-Ariza et al., 2009; Galvão et al., 2017). Hybridization between cultivars is the predominant strawberry breeding method in Brazil (Camargo et al., 1968; Galvão et al., 2017), resulting in the development of genotypes with high performance for the desired phenotypic characteristics. After the crosses, thousands of genotypes, represented by one or two plants originating from seedlings or runners from the mother plant are grown, in general, in the augmented blocks design, and screened. Genotypes selected in this first step are usually cloned and reassessed, now in complete blocks at random, with 
an adequate number of replications (at least two blocks) and plants per plot (approximately ten plants). Those genotypes that confirm their potential in this second step pass to a new cloning and evaluation stage, now in multi-year and multi-environmental trials to assess adaptability and stability. In this third stage, each genotype is represented by at least 40 plants divided into several plots (Marodin et al., 2018). The results of this last stage define the final selection of the superior genotypes to be released to the market (Chandler et al., 2012; Zawadneak et al., 2013). Alternatively, the selected hybrids can undergo further and successive crosses to increase the frequency of favorable alleles.

It is also possible to carry out selfcrosses for two to three generations, followed by crossing the best progenies to restore vigor and productivity, exploring the specific combining ability (Marodin et al., 2018). The method may be useful, although the resulting hybrids are seldom better than those obtained by crossing cultivars.

Traditional breeding has already achieved many significant results for several strawberry agronomic characteristics (Mezzetti et al., 2018). However, classic breeding is laborious and time-consuming. The genetic transformation of strawberries has observed major advances since the first transgenic strawberry appeared in 1990 (Marodin et al., 2018). Therefore, genetic engineering and biotechnology are alternatives to classic breeding, as they offer the possibility of introducing a single or a few genes controlling heterozygous traits directly into the strawberry genome, resulting in the development of new improved materials faster than traditional breeding (Qin et al., 2008; Whitaker et al., 2017; Mezzetti et al., 2018).

\section{Crossing techniques}

The crossing techniques used to breed strawberries vary among institutions. Here, we describe the main procedures adopted by the Strawberry Breeding Program of the State University of the Midwest Paraná (UNICENTRO).

The strawberry floral structure does not pose difficulties to hybridization, and crosses are easily carried out in the field or in the greenhouse. Open flowers in the male parent are collected in the field in the morning and packaged in paper bags. If they do not release enough pollen, flowers are heated with an incandescent lamp to given temperature limits $\left(28\right.$ to $\left.30^{\circ} \mathrm{C}\right)$, so that anther dehiscence occurs. Flower emasculation in the female parent is carried out using tweezers to remove stamens, chalice, and corolla in a single operation. This procedure must be carried out with extreme care, so as not to damage the pistil. To perform the artificial cross, the pollen-donor flowers are agitated over the pistil of the female parent's flower, so that stamens softly touch the stigma. In general, to each pollen-recipient flower, a dehiscent flower is used. After artificial pollination, the pollinated flower is identified and, if necessary, protected to avoid damage from insectpests or birds.

Strawberries obtained from crosses should be harvested as they reach the growth and development peak. After harvesting, fruits are crushed and sieved and the viable seeds are separated from the pulp, washed and placed to dry in an oven with air circulation at $28^{\circ} \mathrm{C}$. Upon drying, achenes are transferred to sterilized containers and stored in cold conditions, at $4^{\circ} \mathrm{C}$. Strawberry achenes have physical dormancy, once the testa and the pericarp are impermeable to water. Therefore, dormancy-breaking treatments should precede sowing. There are several methods to break the dormancy. Seed immersion in sulfuric acid for 35 to 40 minutes has been showing satisfactory germination results (Galvão et al., 2014).

Approximately two months after achene germination, preferably in air-conditioned chambers, seedlings present two to three true leaves. At this stage, seedlings are transplanted to containers containing substrate and transferred to greenhouses, with controlled temperature and humidity for acclimatization. After 75-day acclimatization, plants can be vernalized ( 30 days at 2 to $3^{\circ} \mathrm{C}$ ) and then planted and evaluated in experimental trials, according to the objectives of the breeding program.

\section{Background and status of the strawberry breeding program of the State University of the Midwest Paraná (UNICENTRO)}

In the last ten years, UNICENTRO has been developing research with strawberries. From 2013, UNICENTRO began to carry out strawberry breeding in an intensive way, aiming to obtain cultivars with high yielding potential and good postharvest and sanitary characteristics, superior to the cultivars

Table 1. Genealogy of twelve hybrid populations generated by crossing seven Fragaria $x$ ananassa cultivars. Guarapuava, UNICENTRO, 2019.

\begin{tabular}{|c|c|c|c|c|c|}
\hline \multirow{2}{*}{ Population } & \multicolumn{2}{|c|}{ Parent } & \multirow{2}{*}{ Population } & \multicolumn{2}{|c|}{ Parent } \\
\hline & q &  & & q & $\pi$ \\
\hline 1 & Dover & Aromas & 7 & $\begin{array}{c}\text { Sweet } \\
\text { Charlie }\end{array}$ & Aromas \\
\hline 2 & $\begin{array}{c}\text { Oso } \\
\text { Grande }\end{array}$ & Aromas & 8 & Milsei Tudla & Aromas \\
\hline 3 & Camarosa & Aromas & 9 & Milsei Tudla & $\begin{array}{l}\text { Sweet } \\
\text { Charlie }\end{array}$ \\
\hline 4 & Dover & $\begin{array}{c}\text { Sweet } \\
\text { Charlie }\end{array}$ & 10 & Camarosa & $\begin{array}{l}\text { Sweet } \\
\text { Charlie }\end{array}$ \\
\hline 5 & $\begin{array}{c}\text { Oso } \\
\text { Grande }\end{array}$ & $\begin{array}{l}\text { Milsei } \\
\text { Tudla }\end{array}$ & 11 & $\begin{array}{l}\text { Festival } \\
\text { Flórida }\end{array}$ & Aromas \\
\hline 6 & $\begin{array}{l}\text { Festival } \\
\text { Flórida }\end{array}$ & $\begin{array}{l}\text { Sweet } \\
\text { Charlie }\end{array}$ & 12 & Oso Grande & $\begin{array}{l}\text { Sweet } \\
\text { Charlie }\end{array}$ \\
\hline
\end{tabular}

Note: $q=$ female parent; $\hat{\delta}=$ male parent. 
planted today in Brazil.

Prior to the effective start of the breeding program, Morales et al. (2011) studied the morpho-agronomic and molecular divergence of the Eleven cultivars were assessed and low similarities were found between cultivars Dover and Oso Grande (24\%), Dover and Milsei Tudla (24\%), Dover and Sweet Charlie (24\%), Dover and Camarosa (29\%), and Milsei Tudla and Oso Grande (33\%), thus revealing potential for future crosses and for broadening the genetic base. This genetic information had key importance in the planning, execution, and success of the breeding program, since it allowed defining the best strategies to use the germplasm, guided the choice of parents with interesting germplasm available at UNICENTRO.

genetic characteristics, and helped in the selection of elite hybrids. The studies of Morales et al. $(2011,2012)$ oriented the mating combinations used in breeding, resulting in 12 hybrid populations obtained out of crosses involving seven cultivars (Table 1).

Following the crosses, achenes were germinated according to Galvão et al. (2014) and transferred to in vitro cultivation. After 60 days, seedlings were acclimatized and transplanted to the field in augmented block design. Augmented blocks allow evaluation without replication. In addition, the object of the work is actually the F1 generation. The controls were cultivars Camarosa and Camino Real, the leading cultivars in Paraná. The genetic parameters were estimated based on agronomic, post-harvest, and

Table 2. Fragaria x ananassa hybrids selected using the selection indices of Smith (1936) and Hazel (1943); Mulamba \& Mock (1978); and Genotype/Ideotype, with economic weights established for the selection according to fruit suitability to fresh consumption or to processing. Guarapuava, UNICENTRO, 2019.

\begin{tabular}{lccccccc}
\hline & \multicolumn{3}{c}{ Fresh Market } & & \multicolumn{3}{c}{ Processing } \\
\cline { 2 - 4 } \cline { 6 - 7 } Ranking & Hazel \& & Mulamba & Genotype/ & & Hazel \& & Mulamba & Genotype/ \\
& Smith & \& Mock & Ideotype & & Smith & \& Mock & Ideotype \\
\hline 1 & DA04 & CS10 & CS04 & & DA04 & CS04 & CS04 \\
2 & CS10 & CS04 & CS09 & & CS10 & CS11 & CS01 \\
3 & CS04 & CS11 & CS07 & & CS04 & CS10 & CS07 \\
4 & OT22 & CS09 & CS11 & & OT22 & CS09 & TA16 \\
5 & CA06 & FA16 & CS10 & & CA06 & TA09 & SA15 \\
6 & CS07 & OT21 & FA04 & & CS07 & SA15 & CS09 \\
7 & DA11 & CS07 & CS01 & & DA11 & CA14 & SA14 \\
8 & FSC07 & CA16 & OT21 & & FSC07 & TA16 & DA01 \\
9 & CA16 & TS08 & CA06 & & CA16 & CS07 & OT22 \\
10 & CS11 & CA14 & DA01 & & CS11 & CS13 & CS06 \\
11 & OT21 & DA01 & OT22 & & FA14 & SA12 & SA12 \\
12 & FA14 & TA12 & TA12 & & CS09 & CS01 & CS13 \\
13 & SA08 & FA04 & CA16 & & OT21 & TA07 & TA09 \\
14 & CS09 & CA06 & FA16 & & SA08 & TA12 & CS11 \\
15 & FA02 & FA14 & SA14 & & CS01 & CA06 & CS10 \\
16 & FA04 & TA20 & TS08 & & FA02 & TS08 & TA12 \\
17 & DA01 & FA02 & FA14 & & FA04 & SA14 & CA06 \\
18 & TA16 & TA09 & FSC07 & & DA01 & SA06 & SA06 \\
19 & CS01 & DA04 & TA16 & & TA16 & TA05 & CA14 \\
20 & FA16 & SA14 & DA11 & & FA16 & DA01 & TS08 \\
\hline
\end{tabular}

$\mathrm{DA}=$ Dover $\mathrm{x}$ Aromas; $\mathrm{CS}=$ Camarosa $\mathrm{x}$ Sweet Charlie; OT= Oso Grande $\mathrm{x}$ Milsei Tudla; $\mathrm{CA}=$ Camarosa $\mathrm{x}$ Aromas; FS= Festival Flórida $\mathrm{x}$ Sweet Charlie; FA= Festival Flórida $\mathrm{x}$ Aromas; $\mathrm{SA}=$ Sweet Charlie $\mathrm{x}$ Aromas; $\mathrm{TA}=$ Milsei Tudla $\mathrm{x}$ Aromas; $\mathrm{TS}=$ Milsei Tudla $\mathrm{x}$ Sweet Charlie. phytosanitary characteristics, such as correlation matrices; genotypic, phenotypic and residual variance and covariance; contrasts among hybrids; heritability and genetic variation coefficients, and expected selection gains $(\%)$ for the selected hybrids in relation to the set of hybrids.

Selecting promising materials often becomes a challenge for the breeder in the early stages of the program. Depending on the adopted method, the number of individuals and characteristics evaluated is very large, which makes it impossible to perform comparative tests among all individuals. As a result, three models of selection indexes were proposed to improve the efficiency of selecting several characteristics simultaneously, thus establishing an optimal combination of several characters (Cruz et al., 2014). The rank sum index (Mulamba \& Mock, 1978) was used to hierarchize the hybrids for each characteristic by assigning higher absolute values to those with the best performances. The classic index (Smith, 1936; Hazel, 1943) consists of the linear combination of the phenotypic values of the various economically important characters, with weighting coefficients estimated to maximize the correlation between selection indexes and genotypic aggregate (Cruz et al., 2014). Finally, the genotypeideotype distance index estimates the distance between evaluated hybrids and an ideotype previously defined by the breeder. These indexes revealed the best hybrids and the selection gains were calculated for them. Barth (2017) applied the selection indexes, distinguishing genotypes intended to fresh consumption of those intended to processing by means of attributing different weights to the characteristics of greater interest to one or another purpose. The weights ranged from one (less relevant) to five (more relevant).

At first, we used the three selection indexes individually to select the bestranked hybrids, taking into account their suitability. We selected $2 \%$ of the total hybrids produced or 20 hybrids per index, ranked according to the purpose (Table 2). As there was variation among indexes in hybrid ranking, we 
Table 3. Male and female parents used in the strawberry breeding at UNICENTRO and their respective number of seedlings. Guarapuava, UNICENTRO, 2018.

\begin{tabular}{lcc}
\hline Female Parent (+) & Male Parent $\left({ }^{\text {đ}}\right.$ ) & Seedlings \\
\hline Camino Real & FVFS07 (Festival x Aromas) & 227 \\
Camino Real & FS06 (Festival x Aromas) & 230 \\
Camino Real & CA 16 (Camarosa x Aromas) & 118 \\
Camino Real & DA 11 (Dover x Aromas) & 201 \\
Camino Real & CS04 (Camarosa x Sweet Charlie) & 169 \\
Camarosa & DA 11 (Dover x Aromas) & 07 \\
Camarosa & FVFS07 (Festival x Aromas) & 25 \\
Camarosa & FS06 (Festival x Aromas) & 15 \\
Albion & FVFS07 (Festival x Aromas) & 152 \\
Albion & FS06 (Festival x Aromas) & 191 \\
Monterey & FVFS07 (Festival x Aromas) & 229 \\
Monterey & CA 16 (Camarosa x Aromas) & 18 \\
\hline Total & & 1582 \\
\hline
\end{tabular}

ended up with more than the expected twenty hybrids that should result from a $2 \%$ selection pressure. In a second moment, we took seven hybrids using simultaneously the three indexes for the two purposes, therefore, hybrids with dual aptitude: CS10, CS04, CS09, CS11, CS07, CingA06, and DA01. The hybrid CS04 is the outstanding genotype, since it performed better in all indexes, ranking among the top three for both aptitudes. Hybrids CS10 and CA16, for consumption and processing, respectively, also have good chances of advancing in the program (Table 2).

In 2017, we used some hybrids [CA 16 (Camarosa x Aromas), FS07 (Festival x Aromas), DA 11 (Dover $\mathrm{x}$ Aromas), FS06 (Festival x Aromas), and CS04 (Sweet Charlie x Camarosa)] selected in the first generation as male parents (pollen donors) in crosses with cultivars with good phenotypic adaptability to the local edaphoclimatic conditions: Albion and Monterey (neutral-days) and Camino Real and Camarosa (short-days). The idea here is to build segregating populations with characteristics of neutral and short days.

Crosses were performed and seedlings were produced as described earlier. Seedlings were acclimated, vernalized in a cold chamber and, in 2018, transplanted to beds in augmented block design. Cultivars Albion, Monterey, Camino Real, and Camarosa were used as controls (Table 3). Agronomic and post-harvest characteristics and response to photoperiod drove the screening. The second-generation hybrids are expected to be assessed in trials in several regions of Brazil with the purpose of launching short- and neutral-day productive cultivars, with good post-harvest traits for both fresh and industrial purposes in the shortterm. The best hybrids will be used also as parents in the breeding program, in intra- and inter-specific crosses, to further increase the expression of the genetic variability of the species.

\section{Final considerations and} perspectives

The short- and neutral-day strawberry cultivars appropriate for fresh consumption and/or processing currently available to Brazilian farmers are genotypes developed by foreign breeding programs and do not express the best possible adaptation to the Brazilian soil and climatic conditions. In Brazil, there are very few strawberry breeding initiatives. Therefore, actions to support the national breeding programs will greatly contribute to strengthening the strawberry chain in the country.

Strawberry breeding in Brazil would profit from close cooperation among institutions. The way to overcome the scarcity of human resources and increase chances of launching promising
Brazilian strawberry cultivars is to join efforts towards the breeding work. At the same time, the emergence of new breeding programs, especially in nascent strawberry producing regions, may contribute to boosting the crop in Brazil. It is vital that the breeding programs involve professionals from different areas of plant and food science and technology, to allow for the screening of multiple characteristics. In addition to productivity, genotypes should possess resistance to pathogens and pest-arthropods and tolerance to abiotic factors (such as high temperatures). The fruit physicochemical quality is also a challenge, considering that it is necessary to meet consumer's high expectancies.

Strawberry clones suitable for the fresh market and/or processing developed in Brazil are likely to be very promising in increasing the production of this small fruit in Brazil. These genotypes will allow reducing the dependence on imported plant-matrices, a component that has systematically burned production costs for farmers. It is also fair to expect these genotypes will outyield the imported cultivars, as they will have been developed under tropical and subtropical climate and soil, thus presenting better adaptation to the Brazilian conditions. The next step is introducing genes from ancient Brazilian cultivars such as Campinas, Guarani, Convoy Cascata, Princesa Isabel, and Vila Nova, to broaden the germplasm genetic variability and generate more promising segregating populations as far as attributes of interest are concerned.

\section{REFERENCES}

ANDRIANJAKA-CAMPS, ZN; HERITIER, J; ANÇAY, A; ANDLAUER, W; CARLEN, C. 2017. Evolution of the taste-related and bioactive compound profiles of the external and internal tissues of strawberry fruits (Fragaria $x$ ananassa) cv. 'Clery' during ripening. Journal of Berry Research 7: 11-22.

ANTUNES, LEC; REISSER JUNIOR, C; SCHWENGBER, JE (org). 2016. Morangueiro. Brasília: Embrapa, 2016. 589p.

BARTH, E. 2017. Aptidão de híbridos experimentais de morangueiro obtidos a partir de cruzamentos intraespecifico. Guarapuava: 
Universidade Estadual do Centro-Oeste. 91p. (M.Sc. Thesis)

BRINGHURST, RS. 1990. Cytogenetics and evolution in American Fragaria. Hortscience 25: 879-881.

BRINGHURST, RS; VOTH, V. 1984. Breeding octoploid strawberries. Iowa State Journal of Research 58: 371-381.

BRINGHURST, RS; VOTH, V. 1978. Origin and evolutionary potentiality of the day-neutral trait in octoploid Fragaria. Genetics 90: 510.

BRUN, H; CHÈVRE, AM; FITT, BD; POWERS, S; BESNARD, AL; ERMEL, M; HUTEAU, V; MARQUER, B; EBER, F; RENARD, M; ANDRIVON, D. 2010. Quantitative resistance increases the durability of qualitative resistance to Leptosphaeria maculans in Brassica napus. New Phytologist 185: 285-299.

CAMARGO, LS; ALVES, S; SCARANARI, H; ABRAMIDES, E. 1968. Novos cultivares de morangueiro para a região do «Alto Piracicaba», no Planalto Paulista. Bragantia 27: 117-133

CASTRO, RL; CASALI, VWD; BARRELLA, TP; SANTOS, RHS; CRUZ, CD. 2003. Produtividade de cultivares de morangueiro em sistema de cultivo orgânico. Horticultura Brasileira 21: 227-230.

CHANDLER, CK; FOLTA, K; DALE, A; WHITAKER, VM; HERRINGTON, M. 2012. Strawberry. In: BADENES, ML; BYRNE, DH (ed). Fruitbreeding. New York: Springer. p.305-325.

COCCO, C; ANDRIOLO, JL; CARDOSO, FL; ERPEN, L; SCHMITT, OJ. 2011. Crown size and transplant type on the strawberry yield. Scientia Agricola 68: 489-493.

CRONQUIST, A. 1988. The evolution and classification of flowering plants. Bronx: The New York Botanical Garden. 555p.

CRUZ, CD; CARNEIRO, PCS; REGAZZI, AJ. 2014. Modelos biométricos aplicados ao melhoramento genético. Viçosa: Editora UFV. 668p.

DARROW, GM. 1936. Interrelation of temperature and photoperiodism in the production of fruitbuds and runners in the strawberry. Proceeding of the American Society for Horticultural Science 34: 360-363.

DARROW, GM. 1966. Holt, Rinehart and Winston: the strawberry history breeding and physiology. New York: The New England Institute for Medical Research. 447p.

DURNER, EF; POLING, B. 1987. Flower bud induction, initiation, differentiation and development in the early glow strawberry. Scientia Horticulturae 31: 61-69.

DUSCHESNE, NA. 1766. Histoire naturelle des fraisiers.

FAEDI, W; MOURGUES, F; ROSATI, C. 2002. Strawberry breeding and varieties: situation and perspectives. Acta Horticulturae 567: 51-59.

FAGHERAZZI, AF; BORTOLINI, AJ; ZANIN, DS; BISOL, L; SANTOS, AM; GRIMALDI, F; KRETZSCHMAR, AA; BARUZZI, G; FAEDI, W; LUCCHI, P; RUFATO, L. 2017a. New strawberry cultivars and breeding activities in Brazil. Acta Horticulturae1156:
167-170.

FAGHERAZZI, AF; GRIMALDI, F ; KRETZSCHMAR, AA; MOLINA, AR GONÇALVES, MA; ANTUNES, LEC; BARUZZI, G; RUFATO, L. $2017 \mathrm{~b}$. Strawberry production progress in Brazil. Acta Horticulturae 1156: 937-940.

FAN, L; YU, C; FANG, C; ZHANG, M RANIERI, M; DUBÉ, C; KHANIZADEH, S. 2011. The effect of three production systems on the postharvest quality and phytochemical composition of Orléans strawberry. Canadian Journal of Plant Science 91: 403-409.

F O O D A N D A G R I C U L T U R A L ORGANIZATION. FAOSTAT. 2018. Available at $<$ http://www.fao.org/faostat $>$. Accessed on February 22, 2019.

FEDEROVA, NJ. 1946. Crossability and phylogenetic relations in the main European species of Fragaria. Compte-rendu de I Academie des Sciences de I'URSS 52: 545 547

GABRIEL, A; RESENDE, JTV; ZEIST, AR; RESENDE, LV; RESENDE, NCV; GALVÃO, AG; ZEIST, RA; LIMA FILHO, RB; CORREAA, JVW; CAMARGO, CK. 2018. Phenotypic stability of strawberry cultivars assessed in three environments. Genetics and Molecular Research 17: 01-11.

GALVÃO, AG; RESENDE, LV; GUIMARAES RM; FERRAZ, AKL; MORALES, RGF; MARODIN, JC; CATÃO, HCRN. 2014 Overcoming strawberry achene dormancy for improved seedling production in breeding programs. Idesia 32: 57-62.

GALVÃO, AG; RESENDE, LV; MALUF, WR; RESENDE, JTV; FERRAZ, AKL MARODIN, JC. 2017. Breeding new improved clones for strawberry production in Brazil. Acta Scientiarum. Agronomy 39: 149-155.

GIAMPIERI, F; TULIPANI, S; ALVAREZSUAREZ, JM; QUILES, JL; MEZZETTI, B; BATTINO, M. 2012. The strawberry: Composition, nutritional quality, and impact on human health. Nutrition 28: 09-19.

GIAMPIERI, F; GASPARRINI, M; FORBESHERNANDEZ, TY; MAZZONI, L CAPOCASA, F; SABBADINI, S; ALVAREZSUAREZ, JM; AFRIN, S; ROSATI, C; PANDOLFINI, T; MOLESINI, B; SÁNCHEZSEVILLA, JF; AMAYA, I; MEZZETTI, B; BATTINO, M. 2018. Overexpression of the anthocyanidin synthase gene in strawberry enhances antioxidant capacity and cytotoxic effects on human hepatic cancer cells. Journal of Agricultural and Food Chemistry 66: 581-592.

GIL-ARIZA, DJ; AMAYA, I; LÓPEZ-ARANDA, JM; SÁNCHEZ-SEVILLA, JF; BOTELLA, MA; VALPUESTA, V. 2009. Impact of plant breeding on the genetic diversity of cultivated strawberry as revealed by expressed sequence tag-derived simple sequence repeat markers. Journal of the American Society for Horticultural Science 134: 337-347.

HANCOCK, JF; DRAKE, CA; CALLOW, PW; SERÇE, S. 2005. Genetic improvement of beach strawberry. Hortscience 40: 1644-1645.

HANCOCK, JF; SJULIN, TM; LOBOS, GA. 2008. Strawberries. In: HANCOCK, JF (ed).
Temperate fruit crop breeding. New York: Springer, p.455.

HAZEL, LN. 1943. The genetic basis for constructing selection indexes. Genetics 28: 476-490.

HIRAKAWA, H; SHIRASAWA, K; KOSUGI, S; TASHIRO, K; NAKAYAMA, S; YAMADA, M; KOHARA, M; WATANABE, A; KISHIDA, Y; FUJISHIRO, T; TSURUOKA, H; MINAMI, C; SASAMOTO, S; KATO, M; NANRI, K; KOMAKI, A; YANAGI, T; GUOXIN, Q; MAEDA, F; ISHIKAWA, M; KUHARA, S; SATO, S; TABATA, S; ISOBE, SN. 2014. Dissection of the octoploid strawberry genome by deep sequencing of the genomes of Fragaria species. DNA Research 21: 169-181.

HUMMER, K; HANCOCK, J. 2009. Strawberry genomics: botanical history, cultivation, traditional breeding, and new technologies. In: FOLTA, KM; GARDINER, SE (eds). Genetics and genomics of Rosaceae, plant genetics and genomics: crops and models 6 . Springer. New York. p.413-436.

KENNEDY, C; HASING, TN; PERES, NA; WHITAKER, VM. 2013. Evaluation of strawberry species and cultivars for powdery mildew resistance in open-field and high tunnel production systems. Hortscience 48: 1125-1129.

LUBY, JJ; HANCOCK, JF; DALE, A; SERCE, S. 2008. Reconstructing Fragaria x ananassa utilizing wild $F$. virginiana and $F$. chiloensis: inheritance of winter injury, photoperiod sensitivity, fruit size, female fertility and disease resistance in hybrid progenies. Euphytica 163: 57-65.

LUBY, JJ; SHAW, DV. 2009. Plant breeders' perspectives on improving yield and quality traits in horticultural food crops. Hortscience 44: 20-22.

MARODIN, JC; RESENDE, JTV; GALVÃO, AG; RESENDE, LV; RESENDE, NCV; ZEIST, AR. 2018. Melhoramento genético do morangueiro. In: RAMPIM, L; SANTOS, LA; GAVA, E; SPLIETHOFF, J (eds). Tópicos avançados em produção vegetal. Guarapuava: Apprehendere, p.47-72.

MEZZETTI, B; BALDUCCI, F; CAPOCASA, F; ZHONG, CF; CAPPELLETTI, R; DI VITTORI, L; MAZZONI, L; GIAMPIERI, F; BATTINO, M. 2016. Breeding strawberry for higher phytochemicals content and claim it: is it possible? International Journal of Fruit Science 16: 194-206.

MEZZETTI, B; GIAMPIERI, F; ZHANG, Y; ZHONG, C. 2018. Status of strawberry breeding programs and cultivation systems in Europe and the rest of the world. Journal of Berry Research 8: 205-221.

MICHALSKA, A; CARLEN, C; HERITIER, J; ANDLAUER, W. 2017. Profiles of bioactive compounds in fruits and leaves of strawberry cultivars. Journal of Berry Research 7: 71-84.

MORALES, RGF; RESENDE, JTV; FARIA, MV; SILVA PR.; FIGUEIREDO AST; CARMINATTI, R. 2011. Divergência genética em cultivares de morangueiro, baseada em caracteres morfoagronômicos. Revista Ceres 58: 323-329. 
MORALES, RGF; FARIA, MV; RESENDE, JTV; RISSINI, ALL; CARMINATTI, R; FARIA, CMD. 2012. Produtividade do morangueiro em função da adubação orgânica complementar em cultivo protegido. Ambiência 8: 23-33.

MULAMBA, NN; MOCK, JJ. 1978. Improvement of yield potential of the Eto Blanco maize (Zea mays L.) population by breeding for plant traits. Egyptian Journal of Genetics and Cytology 7: 40-51.

NELLIST, CF. 2018. Disease resistance in polyploid strawberry. In: HYTÖNEN, T; GRAHAM, J; HARRISON, R (eds). The genomes of Rosaceous berries and their wild relatives. Springer International Publishing, Cham. p.79-94. DOI: 10.1007/978-3-31976020-9 7

OLIVEIRA, ACB; BONOW, S. 2012. Novos desafios para o melhoramento genético da cultura do morangueiro no Brasil. Informe Agropecuário 33: 21-26.

OLIVEIRA, ACB; ANTUNES, LEC. 2016. Melhoramento genético e principais cultivares. In: ANTUNES, LEC; REISSER JUNIOR, C; SCHWENGBER, JE (eds). Morangueiro. Brasília: Embrapa. p. 133-147.

PINCOT, DDA; POORTEN, TJ; HARDIGAN, MA; HARSHMAN, JM; ACHARYA, CB; COLE, GS; GORDON, TR; STUEVEN, M; EDGER, PP; KNAPP, SJ. 2018. Genomewide association mapping uncovers Fw1, a dominant gene conferring resistance to Fusarium wilt in strawberry. Genes Genomes Genetics 8: 1817-1828.

POLAND, J; RUTKOSKI, J. 2016. Advances and challenges in genomic selection for disease resistance. Annual Review of Phytopathology 54: 79-98.

QIN, Y; SILVA, JAT; ZHANG, L; ZHANG, S. 2008. Transgenic strawberry: State of the art for improved traits. Biotechnology Advances 26: 219-232.

RICHTER, AF; FAGUERAZZI, AF; ZANIN, DS; SILVA, S; ARRUDA, AL; KRETZSCHMAR, AA; RUFATO, L. 2018. Produtividade e qualidade de cultivares de morangueiro sob cultivo de solo e semi-hidropônico. Revista Cientifica Rural 20: 193-203.

ROUSSEAU-GUEUTIN, M; GASTON, A; AINOUCHE, A; AINOUCHE, ML; OLBRICHT, K; STAUDT, G; RICHARD, L; DENOYES-ROTHAN, B. 2009. Tracking the evolutionary history of polyploidy in
Fragaria L. (strawberry): new insights from phylogenetic analyses of low-copy nuclear genes. Molecular Phylogenetics and Evolution 51: 515-530.

SANTOS, AM. 1999. Melhoramento genético do morangueiro. Informe Agropecuário 20: 24-29.

SHAW, DV; LARSON, KD. 2008. Performance of early-generation and modern strawberry cultivars from the University of California breeding program in growing systems simulating traditional and modern horticulture. Journal of Horticultural Science \& Biotechnology 83: 648-652.

SENANAYAKE, YDA; BRINGHURST, RS. 1967. Origin of Fragaria polyploids. I., cytological analysis. American Journal of Botany 54: 221-223.

SHULAEV, V; SARGENT, DJ; CROWHURST, RN; MOCKLER, TC; FOLKERTS, O; DELCHER, AL; JAISWAL, P; MOCKAITIS, K; LISTON, A; MANE, SP; BURNS, P; DAVIS, TM; SLOVIN, JP; BASSIL, N; HELLENS, RP; EVANS, C; HARKINS, T; KODIRA, C; DESANY, B; CRASTA, OR; JENSEN, RV; ALLAN, AC; MICHAEL, TP; SETUBAL, JC; CELTON, J-M; REES, DJG; WILLIAMS, KP; HOLT, SH; ROJAS, JJR; CHATTERJEE, M; LIU, B; SILVA, H; MEISEL, L; ADATO, A; FILICHKIN, SA; TROGGIO, M; VIOLA, R; ASHMAN, T-L; WANG, H; DHARMAWARDHANA, P; ELSER, J; RAJA, R; PRIEST, HD; BRYANT, DW; FOX, SE; GIVAN, SA; WILHELM, LJ; NAITHANI, S; CHRISTOFFELS, A; SALAMA, DY; CARTER, J; GIRONA, EL; ZDEPSKI, A; WANG, W; KERSTETTER, RA; SCHWAB, W; KORBAN, SS; DAVIK, J; MONFORT, A; DENOYESROTHAN, B; ARUS, P; MITTLER, R; FLINN, B; AHARONI, A; BENNETZEN, JL; SALZBERG, SL; DICKERMAN, AW; VELASCO, R; BORODOVSKY, M; VEILLEUX, RE; FOLTA, KM. 2011. The genome of woodland strawberry (Fragaria vesca). Nature Genetics 43: 109-116.

SINGH, A; SINGH, BK; DEKA, BC; SANWAL, SK; PATEL, RK; VERMA, MR. 2011. The genetic variability, inheritance and interrelationships of ascorbic acid, beta-carotene, phenol and anthocyanin content in strawberry (Fragaria $x$ ananassa Duch.). Scientia Horticulturae 129: 86-90.

SMITH, HFA. 1936. Discriminant function for plant selection. Annals of Eugenics 7: 240-250.

SONE, K; MOCHIZUKI, T; OKIMURA, M; NOGUCHI, Y; KITADANI, E. 2003. Inheritance of ascorbic acid content in strawberry fruits. Journal of the Japanese Society for Horticultural Science 72: 141-147.

STAUDT, G. 2009. Strawberry biogeography, genetics and systematics. Acta Horticulturae 842: 71-84.

STEWART P; FOLTA, KMA. 2010. A review of photoperiodic flowering research in strawberry (Fragaria spp.). Critical Reviews in Plant Sciences 29: 01-13.

TAZZO, IF; FAGHERAZZI, AF; LERIN, SK; AIKE, A; RUFATO, L. 2015. Exigência térmica de duas seleções e quatro cultivares de morangueiro cultivado no planalto catarinense. Revista Brasileira de Fruticultura 37: 550558.

TENNESSEN, JÁ; GOVINDARAJULU, R; ASHMAN, TL; LISTON, A. 2014. Evolutionary origins and dynamics of octoploid strawberry subgenomes revealed by dense targeted capture linkage maps. Genome Biol Evol 6: 3295-3313

VIEIRA, SD; SOUZA, DC; MARTINS, IA; RIBEIRO, GHMR; RESENDE, LV; FERRAZ, AKL; GALVÃO, AG; RESENDE, JTV. 2017. Selection of experimental strawberry (Fragaria $x$ ananassa) hybrids based on selection indices. Genetics and Molecular Research 16: 1-11.

WHITAKER, VM; LEE, S; OSORIO, LF; VERMA, S; ROACH, JA; MANGANDI, J; NOH, YH; GEZAN, S; PERES, N. 2017. Advances in strawberry breeding at the University of Florida. Acta Horticulturae 1156: 1-6.

WHITAKER, VM; HASING, T; CHANDLER, CK; PLOTTO, A; BALDWIN, E. 2011. Historical trends in strawberry fruit quality revealed by a trial of University of Florida cultivars and advanced selections. Hortscience 46: 553-557.

WITTER, S; RADIN, B; LISBOA, BB; TEIXEIRA, JSG; BLOCHTEIN, B; IMPERATRIZ-FONSECA, VL. 2012. Desempenho de cultivares de morango submetidas a diferentes tipos de polinização em cultivo protegido. Pesquisa Agropecuária Brasileira 47: 58-65.

ZAWADNEAK, MAC; SCHUBER, JM; MÓGOR, ÁF. 2013. Como produzir morangos. Curitiba: UFPR, 280p. 